\title{
Financial Inclusion Among Rural Households in Ghana
}

\author{
${ }^{1}$ Agyemang Frimpong (Ph.D.) ${ }^{2}$ Ronald Osei Mensah (M.Phil.) \\ ${ }^{1}$ Lecturer, Ghana Institute of Management and Public Administration (GIMPA) \\ ${ }^{2}$ M.Phil. Graduate, Department of Sociology and Anthropology, University of Cape Coast

\begin{abstract}
\end{abstract} \\ In 1991, Cooperative for Assistance and Relief Everywhere (CARE) International, a leading humanitarian \\ organization, launched a unique savings-based microfinance program called a Village Savings and Loan \\ Association (VSLA). Today, the model is being replicated across sub-Saharan Africa. Although previous studies \\ have shown substantial benefits from participating in the VSLA program, these studies likely suffer from selection \\ bias and other methodological weaknesses. This study attempts to improve upon the existing work by examining \\ the impact of one of the first VSLA programs, commissioned by the Progressive Excellence Youth Organisation \\ (PEYORG) in the Asikuma Odoben Brakwa District in the Central Region of Ghana, using both quantitative data \\ from individual surveys, and qualitative data from Focus Group Discussions (FGD) and key interviews. In order \\ to control for selection bias, this study utilizes a control group of new VSLA members who are still in the initial \\ training phase, and also statistically controls for differences in demographic characteristics including age, gender, \\ marital status and education, which may affect program impact. The results suggest that participation in the \\ program has an overall positive impact on various indicators of household and individual welfare, including asset \\ expenditure levels, the development of Income-Generating Activities (IGAs), education expenses, access to health \\ services, nutritional levels, and quality of housing. Such positive results are particularly encouraging given the \\ long-term sustainability of the VSLA model - the program does not rely on outside donor funding and does not \\ require continued support from the founding organization. Overall, these results suggest that the VSLA model is \\ both successful and sustainable. Furthermore, it may offer potential teaching benefits for other Community-Based \\ Finance Organisations (CBFO) in developing countries.
}

Keywords: Cooperative for Assistance and Relief Everywhere, Village Savings and Loan Association, Progressive Excellence Youth Organisation, Income-Generating Activities, Community-Based Finance Organisations

DOI: $10.7176 / J E S D / 11-4-21$

Publication date: February $29^{\text {th }} 2020$

\subsection{Introduction}

Economic theory endorses direct relationship between investment and economic growth to saving rate. It is implied that financial exclusion of a vast majority represents a missed opportunity of an enormous potential for economic development. Growth is inclusive when it allows all members of a society to participate in and contribute to the growth process on an equal basis regardless of their individual circumstances. The State, formal financial system and community-based organizations are incidental in mitigating or reducing poverty while posing as the three pillars in achieving societal transformation (Thorat, 2006). Financial system can play a role in reinforcing many of the objectives of the Sustainable Development Goals (SDGs). Financial inclusion has been identified as a facilitator for seven of the 17 Sustainable Development Goals (SDG's. Financial exclusion implies limited accessibility of individuals to formal financial services. It is estimated that more than three billion people are financially excluded around the world (Agrawal, 2008).

Financial inclusion has become a subject of considerable interest among policy makers, researchers, and other stakeholders (Bank, 2014). In international forums, such as the Group of Twenty (G-20), financial inclusion has moved up the reform agenda by stimulating the Financial Inclusion Action Plan for 2015 onwards and endorsing the G-20 High-Level Principles for Digital Financial Inclusion. The group sees financial inclusion as an essential tool to reduce extreme poverty and boost shared prosperity, and it is committed to a global work plan to achieve Universal Financial Access (UFA) (Online, 2017).

\subsection{Statement of the Research Problem}

Formal financial services in most developing economies serve only a minority, often not more than 20-30 per cent of the population. Financial inclusion denotes delivery of financial services at an affordable cost to vast sections of disadvantaged and low-income groups. An inclusive financial sector provides effective, ongoing access to all sections of the population and all scales of enterprise (Triki \& Faye, 2013).

Availability of cheap and easy credit has been accorded prime importance in the financial inclusion agenda as the poor requires access to timely and adequate credit more than any other financial service. Despite the spread of formal banking in rural areas as part of the nationalisation drive, rural indebtedness to moneylenders has remained 
unaltered due to inherent issues. The main hurdle faced by banks in financing the poor is the high transaction cost in reaching out to a large number of people who require small amounts of credit at frequent intervals. This is found true for savings as well. The poor can afford to save smaller amounts at frequent intervals rather than depositing a lump sum amount. Interestingly the poor also find banks as an institutional set up favouring elites and even when they tried to access it foregoing their employment days, they had to face a number of hurdles including the procedural hassles, not very sure of getting the loan in time. This mutual inconvenience has made the poor and the banks to avoid each other, the poor being attracted to the local moneylender who would attend to their immediate needs without bothering to pledge or to comply with the procedural formalities at the expense of foregoing employment days. Considering the envisaged benefits of financial inclusion on rural households, it was considered appropriate to undertake this study to assess the impact of financial inclusion on rural development to give credence to financial inclusiveness.

\subsection{Research Questions}

This study sought to analyse the impact financial inclusion has had on rural households in Ghana. Specifically, the questions to be answered were:

a. What is the status of financial inclusion among rural households in Ghana?

b. What factors determine the level of financial exclusion/inclusion and is there any significant influence of microfinance models?

\subsection{Research Hypotheses/Propositions}

Rogers (1996) defines hypotheses as "single tentative guesses, good hunches - assumed for use in devising theory or planning experiments intended to be given a direct experimental test when possible".

The alternative hypothesis for the study is:

"Financial Inclusion has significant impact on the socio-economic wellbeing of rural households in Ghana"

This is tested against the null hypothesis which states that:

"Financial Inclusion has no significant impact on the socio-economic wellbeing of rural households in Ghana"

\subsection{Study Assumption/s}

This study is anchored on the assumption that Ghana has enough policies on financial inclusion. And that regulatory body of financial institutions are passionate about extending services to rural households in Ghana. The study also assumed that respondents gave truthful answers void of social desirability. In order to achieve this, the research instruments were tested through a pilot study and enumerators were trained very well to guide respondents in their answers.

\subsection{Significance and Justification of the Study}

This study was significant in two ways.

1. It added to the research base on financial inclusion in Ghana, with direct relation to rural development.

2. It also provided useful information on the impact of financial inclusion on rural development and identified the bottlenecks that need to be addressed by stakeholders.

\subsection{Literature Review}

\subsection{Conceptual and Theoretical framework}

Financial inclusion is central to economic empowerment in rural communities, as it forms the foundation for sustainable economic development of the less privileged in the society (Oji, 2015). By engaging in economic activities where goods and services are traded for cash, people become part of economic clusters. Oji suggests that the amalgamation of economic clusters has an impact on the growth of local economic systems, resulting in sustained development. Thus, in order for sustained socio-economic development to occur, people should be encouraged to engage in more economic activities where financial transactions take place. To do this, people often need to have bank accounts at formal financial institutions. However, studies have shown that there are numerous barriers preventing especially the rural poor from entering the formal financial system. Some of these barriers include strict 'Know Your Customer' regulations, the cumbersome paperwork associated with opening banking accounts, mandatory deposits, bank charges and the distance from villages to towns, where most formal financial institutions are normally located. Considering this, many rural people may opt to use informal financial institutions, which are risky and mostly unregulated. 


\subsection{Conceptual Framework of Financial Inclusion and Rural Development}

A conceptual framework explains either graphically or in a narrative form, the main things to be studied- the key factors constructs or variables and the presumed relationships among them (Miles, 1994). Usually expressed abstractly through word models, a conceptual framework is the conceptual basis for many theories.

Financial inclusion can be described as the practice of ensuring access to financial services on time with adequate credit needed by vulnerable groups such as low-income groups at an affordable cost (Committee, 2008). It is the delivery of banking services at an affordable cost to the vast sections of disadvantaged and low-income groups (Leeladhar, 2006).

Therefore, financial inclusion refers to delivery of financial system of an economy to its members. The financial inclusion has an important role to play in achieving poverty reduction. It allows access to fund and savings for productive investment, and facilitating capital inflows and remittances. Through affordable cost, financial inclusion enables the poor to participate in investment activities in both physical and human capital, hence increase the productivity of the poor community. It is very important to note that through financial intermediation function, it reduces transaction costs and facilitates inward investment, and making capital available for investment in better technologies (Miller, 2005).

Figure 1 displays the composition of the term" financial inclusion"; it displays that if the low-income group, illiterates or the less educated, rural dwellers and the financially disadvantaged people in the society, all have access to the necessary financial services by bringing the services closer to them at an affordable cost, it will enhance poverty reduction and rural development.

Figure 2: Financial Inclusion and Poverty Reduction

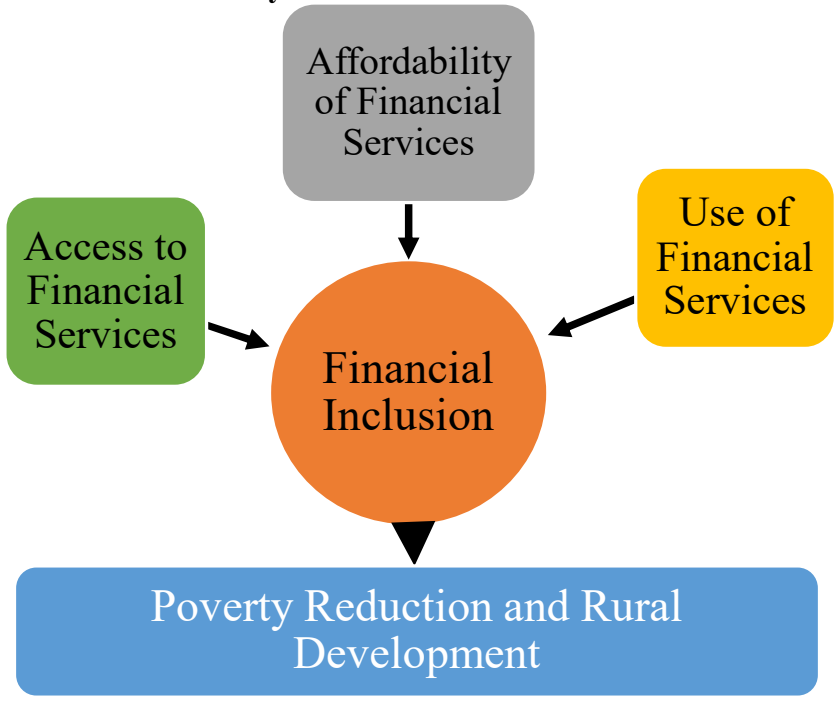

Source: (Authors’ own construct, 2020)

Figure 1 also shows that if the poor have access to affordable financial services, they would be encouraged to save funds in a secure place, this is specifically through the opening of bank accounts (or other savings facilities) and insurance that allow the poor to establish a buffer against shocks, thus reducing vulnerability and minimizing the need for other coping strategies such as asset sales that may damage long-term income prospects of the poor (Richter, 2011). Financial inclusion of the rural community can impact on rural poverty both indirectly, through its positive impact on the productive growth in the rural community, and more directly, to the extent that financial inclusion can widen access to financial services for the poor and finally reduce the poverty level.

Rural poverty reduction can be explained by way of improved living standards, increased incomes which can accelerate asset building and their maintenance, even in the presence of negative household shocks (Miller, 2005). Financial inclusion specifically available financial services at affordable cost can contribute significantly to poverty reduction. Meanwhile, it cannot directly multiply the net assets of the poor, but it can enable them to have important investments that can help them take advantage of income generating opportunities. Without such services, it could be difficult for the poor rural dwellers to realize their economic potentials (Odell, 2010). 


\subsection{Research Methodology/Strategy}

The research was conducted by applying both quantitative and qualitative methods. A systematic approach to understanding the financial inclusion sector was achieved by analysing sector specific data and interviewing experts and clients of various financial inclusion platforms to obtain national insight on coverage and contribution to the development of Ghana. The study made use of questionnaires and interviews conducted on stakeholders' rural households across Ghana.

\subsection{Research Design and Approach}

Research is a scientific and systematic search for pertinent information on a specified area and to solve the research problem. It involves gathering, recording and analysing critically relevant facts about any problem along with logic behind them. It is the manipulation of things, concepts or symbols for the purpose of generalising to extend, correct, verify knowledge, whether that knowledge aids in construction of theory or in practice of an art (Kothari, 2005). It is directed towards development of an organised body of knowledge \& discovery of new insights into unsolved problems. Ragin also defines research design as the plan for the collection and analysis of evidence that enables the researcher to answer the research question posed (Ragin, 1994). Quantitative methods are generally aimed at gathering facts whereas qualitative methods are more useful for exploring people's experiences and knowledge.

The quantitative aspect of the study focuses on a small-scale sample survey of current Village Savings and Loan Association (VSLA) members and a control group of incoming members. The results from the survey are then crosschecked using information gathered from focus group discussions and interviews with key informants.

Impacts are assessed at both the individual and the household level, primarily using the data gathered from the questionnaire. As it is very difficult to measure community-level impacts in a quantitative survey without the use of a control group of eligible non-members, impacts at the community level are addressed briefly, based primarily on information gathered through focus group discussions. The community-level assessment is predominantly focused on capturing any major externalities of the program intervention. This study focuses on economic and social impacts and, in conclusion, briefly examines the sustainability of the VSLA model.

\subsection{Study Population}

The study is limited to VSLA groups in the Asikuma Odoben Brakwa District in the Central region of the republic of Ghana. According to Ghana Statistical Service (GSS, 2015) the Central region is one of the poorest regions in Ghana. Among the number of districts in the Central region, the Asikuma Odoben Brakwa District was purposively selected due to the presence of VSLA groups formed by the Progressive Excellence Youth Organisation (PEYORG) with the objective of promoting economic empowerment and improving sanitation in the district. Four (4) survey communities (Asikuma, Adukwaa, Breman Budum, and Breman Bosomase) were randomly selected from the list of VSLA communities in targeted district. Data was collected from old and new members of fourteen groups in the four communities. The total number of groups in the Asikuma Odoben Brakwa District under the PEYORG programme is presented in table 1.

Table 10: Communities under the PEYORG programme in the Asikuma Odoben Brakwa District

\begin{tabular}{lc}
\hline Name of Communities & Number of groups \\
\hline Edukrom & 1 \\
Breman Ewusem & 2 \\
Nyanakyere & 1 \\
Adukwaa & 3 \\
Breman Bosomase & 2 \\
Atu Danda & 1 \\
Breman Bedum & 3 \\
Adukwa & 2 \\
Abokua & 2 \\
Asikuma & 1 \\
Eniehu & 6 \\
Apagya & 6 \\
Mantemankebi & 1 \\
\hline Total & 2 \\
\hline
\end{tabular}

Source: Field Survey (2020) 


\subsection{Sample Size}

As VSLAs operate with a minimum number of fifteen (15) and a maximum number of twenty-five (25), the sample size of the study involving the four communities was purposively limited to hundred (100) due to convenience and financial constraints. A total of 438 members both (old and new) from 26 groups comprising 17 old groups and 9 new groups constituted the sample frame of VSLA members in the Asikuma Odoben Brakwa District under the PEYORG programme. Out of this frame, the total number of members from the selected communities was 147. Therefore, using the Turner (2003) sampling technique which is given by:

$$
\begin{aligned}
& \boldsymbol{n}=\frac{\boldsymbol{N}}{\mathbf{1}+\boldsymbol{N}(\alpha)^{2}} \\
& \text { Where: } \\
& n=\text { the sample size, } \\
& N=\text { the sample frame } \\
& \alpha=\text { the margin of error }(5 \% \text { or } 0.05) .
\end{aligned}
$$

The sample size was 107 for which the researcher conveniently selected 100 comprising fifty-two (52) old members and forty-eight (48) new members as treatment and control groups respectively.

\subsection{Sample Technique}

A sample is a portion or subset of a larger group called a population (Fink, 2003). According to Borg and Gall (1996) sampling is a research technique used for selecting a given number of subjects from a target population as a representative of the population.

At the time of the survey, there were 26 VSLA groups in Asikuma Odoben Brakwa District under the PEYORG programme. The list of VSLA groups operating in the four communities were obtained from the programme office of PEYORG. With a sample size of 100, 52 old members were purposely selected from 83 old members and 48 new members were selected from 64 new members in the four communities. The number was evenly distributed among the selected communities in the table below.

Table 11: Sample size

\begin{tabular}{lcc}
\hline Community & Number of New Members & Number of Old Members \\
\hline Asikuma & 12 & 13 \\
Adukwaa & 12 & 13 \\
Breman Bedum & 12 & 13 \\
Breman Bosomase & 12 & 13 \\
\hline Total & 48 & 52 \\
\hline
\end{tabular}

Source: Field Survey, 2020

\subsection{Sources of data}

The study collected both primary and secondary data. The primary data was collected using a structured questionnaire for both old and new VSLA members. The Secondary source data was collected using desk review of available literature, journals and academic libraries so as to compare with primary data collected.

The quantitative data was collected by questionnaire, which was designed as the result of intensive literature search, programme theory and conceptual framework of impact analysis of financial inclusion on rural development. A Pilot study was conducted on a self-help group at Abokobi in the Greater Accra region order to test flow, logic, acceptability and suitability of questions in the questionnaire.

The qualitative data was collected through a focus group discussion involving community members and in-depth interviews with key informants including management of VSLA groups.

The information collected during quantitative research approach was explained by qualitative information explored.

\subsection{Research Instruments}

The study made use of both open and closed ended questionnaire to ascertain much information in the interview process.

\subsection{Results and Discussion}

The section presents the empirical results of the study. First, it presents a description of the socio-economic backgrounds of respondents from the Village Savings and Loans (VSL) in the Asikuma Odoben Brakwa district of the Central Region of Ghana. This section also identifies common financial and social intermediation services offered. It further assesses the collective influences of these services on the livelihood strategies as well as the resulting outcomes and impacts on respondents comparatively. 
Data analysis is a critical stage in the research process, as it carries the potential to decrease or amplify the result expected. Data analysis is also the critical stage for analysing and presenting the outcomes of the research done.

\section{Basic Characteristics of Respondents}

Table 3 presents the means of the key characteristics of both the treatment group and the control group. Many of these characteristics are considered to be time-invariant and should not be affected by participation in the VSLA program. If the control group is to be considered valid, the basic characteristics of its members should not vary significantly from those of the treatment group. For variables that are continuous, t-tests are used to assess whether the means of the two groups are statistically different from each other. For the variables that are categorical, the values are broken down and percentages then compared across the treatment and control group using a proportion test. The results of the t-tests, as well as the values from the proportion test, are presented in the final column. The two values may be interpreted in the same manner; thus, if the value is greater than 1.64 , then the difference between the treatment and control group may be considered statistically significant at the 10 percent level.

Table 3: basic Characteristics of Respondents

\begin{tabular}{|c|c|c|c|}
\hline Control Variable & Treatment Group & Control Group & Test Statistic \\
\hline $\mathbf{N}$ & 52 & 48 & \\
\hline Gender ( $\%$ Female $)$ & 67.3 & 70.8 & 0.5771 \\
\hline Age & 37.95 & 33.64 & $2.1759 * * *$ \\
\hline Age at time of joining & 33.19 & 33.64 & 0.2341 \\
\hline \multicolumn{4}{|l|}{ Relation to HHH (\%) } \\
\hline Household head (HHH) & 42.5 & 32 & 1.2765 \\
\hline Spouse & 47.5 & 50 & 0.2972 \\
\hline Child & 9.1 & 18 & 1.6288 \\
\hline Other relation & 0.9 & 0 & 0.6474 \\
\hline \multicolumn{4}{|l|}{ Marital status (\%) } \\
\hline Married & 75.00 & 70.0 & 0.6733 \\
\hline Widowed & 8.33 & 8.0 & 0.0720 \\
\hline Divorced & 5.0 & 8.0 & 0.7575 \\
\hline Separated & 1.67 & 0 & 0.9183 \\
\hline Single & 10.0 & 14.0 & 0.7542 \\
\hline \multicolumn{4}{|l|}{ Educational attainment (\%) } \\
\hline No education & 13.34 & 20.0 & 1.1004 \\
\hline Primary & 47.50 & 20.0 & $3.3433 * * *$ \\
\hline Junior High & 15.83 & 32.0 & $2.3753 * * *$ \\
\hline Senior High & 23.33 & 28.0 & 0.6428 \\
\hline Number of children & 3.725 & 2.62 & $2.7184 * * *$ \\
\hline $\begin{array}{l}\text { Number of children at time of } \\
\text { joining }\end{array}$ & 3.075 & 2.62 & 1.1403 \\
\hline Average household size & 5.033 & 4.92 & 0.316 \\
\hline $\begin{array}{l}\text { Savings prior to joining VSLA? } \\
(\%)\end{array}$ & 47.9 & 36.0 & 1.4211 \\
\hline $\begin{array}{llll}\text { Access to loans prior to } \\
\text { joining? }(\%)\end{array}$ & 7.62 & 8.0 & 0.0827 \\
\hline
\end{tabular}

Source: (Field Survey, 2020)

From Table 3, we can see that the control group has slightly more female respondents than the treatment group. However, the difference is not statistically significant. The treatment group is significantly older than the control group. However, there does not appear to be a significant difference between the ages at which members of each group joined the VSLA program

From Table 4, although there does not appear to be any substantial difference in asset ownership between the treatment and the control group, with a few notable exceptions, there is a statistically significant difference in asset expenditures. In terms of asset ownership, members of the treatment group own, on average, a greater number of livestock than members of the control group. There is a sub-set of the savings literature, which discusses the role 
of livestock as an important form of savings. Livestock provide a steady source of nutrition and draught power and may be easily sold when there is an urgent need for money within the household (Deshingkar, 2008). Therefore, the difference in livestock ownership between the treatment and the control group may be deemed quite important.

Table 4: Household Assets

\begin{tabular}{|c|c|c|c|}
\hline & Treatment Group & Control Group & $\begin{array}{l}\text { Test } \\
\text { Statistic }\end{array}$ \\
\hline $\mathbf{N}$ & 52 & 48 & \\
\hline \multicolumn{4}{|l|}{ Livestock } \\
\hline Number of cows & 1.966387 & 0.86 & $1.7678^{*}$ \\
\hline Goats & 0.7142857 & 0.46 & 0.8119 \\
\hline Chicken/Ducks & 7.798319 & 6.54 & 0.8835 \\
\hline \multicolumn{4}{|l|}{ Transportation } \\
\hline Motorcycles & 0.0840336 & 0.04 & 0.9336 \\
\hline Bicycles & 0.7478992 & 0.8 & 0.4248 \\
\hline \multicolumn{4}{|l|}{ Electronics } \\
\hline Radio & 0.8833333 & 0.76 & 1.0153 \\
\hline Television & 0.1092437 & 0.04 & 1.4451 \\
\hline Cell Phone & 1.033333 & 0.78 & $1.708^{*}$ \\
\hline Fan & 0.0583333 & 0.04 & 0.3706 \\
\hline \multicolumn{4}{|l|}{ Other household items } \\
\hline Farm tools & 0.9916667 & 1.64 & $2.6975 * * *$ \\
\hline Mosquito net & 2.825 & 2.54 & 1.235 \\
\hline Lantern & 1.441667 & 1.3 & 0.5374 \\
\hline Sewing machine & 0.302521 & 0.28 & 0.2462 \\
\hline Refrigerator & 0.0840336 & 0.02 & 1.4092 \\
\hline Metal cooking pots & 7.525 & 6.14 & 1.6302 \\
\hline 2009 Asset Expenditure GHS & 615.28 & 287.88 & $4.7292 * * *$ \\
\hline $\begin{array}{l}2009 \text { Education Expenditure } \\
\text { GHS }\end{array}$ & 418.82 & 136.70 & $1.8751 *$ \\
\hline
\end{tabular}

Source: (Field Survey, 2020)

Members of the control group appear to own, on average, more farm tools than members of the treatment group. However, given the relatively minor expense of a farm tool compared to the other items in the table, this differential may not be very important. The final row of the table indicates a statistically significant difference in asset expenditures.

\section{Sources of Income}

The four-phase training program in the VSLA methodology involves substantial training in Income Generating Activities (IGAs). In Table 5, we can see a measurable impact of this training, when combined with the other benefits of participating in the VSLA, on the number of IGAs pursued by households in the treatment group. Households in the treatment group are, on average, involved in 1.91 IGAs, compared to the 1.39 IGAs operated by households in the control group - a difference that is statistically significant at the 1 percent level.

Table 5: Income Generating Activities (IGAs)

\begin{tabular}{lrrr}
\hline & Treatment Group & Control Group & \multicolumn{2}{c}{ Test Statistic } \\
\hline Number of IGAs & 1.9107 & 1.3877 & $4.5775^{* * *}$ \\
Type of IGA (\%) & & & \\
Agriculture & 75.8 & 68.0 & 1.0548 \\
Business & 46.7 & 58.0 & 1.3466 \\
Fishing & 9.2 & 4.0 & 1.1550 \\
Carpentry & 0.83 & 0.0 & 0.6474 \\
Tailoring & 5.8 & 2.0 & 1.0754 \\
\hline$* * * \mathrm{p}<0.01,{ }^{* *} \mathrm{p}<0.05,{ }^{*} \mathrm{p}<0.1$ & & &
\end{tabular}

Source: (Field Survey, 2020) 
The types of IGAs, however, are similar across the two groups. The main economic activities of both groups are agriculture and business. Those involved in business are mainly engaged in the sale of food stuff, fuel wood or charcoal. A small percentage of both groups are also involved in tailoring, which is considered to be a highlyskilled trade and is often incorporated into VSL training.

\section{Impacts of VSLA Participation}

Overall, VSLA members report an overwhelmingly positive impact from program participation. However, from Tables 4 and 5 it appears as if the current members have benefited more from program participation than the dropouts. Nonetheless, in general, dropouts do not appear to have been negatively impacted, but rather simply experienced little effect from their participation in the VSLA program. Without in-depth interviews it is impossible to determine whether the dropouts left the program because they saw little change in their social status, or if they saw little change because they left the program too quickly, without giving it a chance to yield positive changes.

\subsection{Conclusions}

In this section, the summary and conclusions of the results are presented. Though poverty is said to be decreasing at an increasing rate in Africa, the livelihoods of the rural poor especially women are constrained by limited access to financial services as well as non-financial services including business development skills and entrepreneurial capacities. There is however, growing evidence that financial inclusion which involves credit, savings, payment services, money transfers and insurance to poor and low-income households and their micro-enterprises using innovative methodologies such as VSLA is a more sustainable strategy for addressing poverty and hence development.

From the field interviews, access to affordable financial services, especially credit opens up livelihood opportunities by empowering the poor. The extent and quantum of indebtedness at a reasonable level of interest sourced out from the organised sector is an indicator of development since availability of finances boost up the economic activity and capital formation in a region.

Recognizing the need for finance as a critical input for development, Bank of Ghana has promoted the financial inclusion drive in the country to include vast majority of unbanked masses into banking fold. VSLA led inclusion has been recognized as one of the elements of the multi-pronged strategy that promotes financial inclusion. In addition, most people join VSLA to get soft loans and usually delinquent rates are low. This is because the community knows whoever comes for the loan and also borrowers serve as a check on each other in honouring repayment of loans. The study found out that VSLA plays a crucial role in financial inclusion especially at the rural household level. This study hopes to add to and improve upon the available empirical evidence that confirms the hypothesis of an overall positive impact on the lives of rural households through VSLA. The results of the study validate many of the findings in the existing literature, offer some potentially new insights and suggest several lessons for the study of microfinance in general.

\subsection{Recommendation}

A good management system for the groups is key to sustaining the groups and ensuring that the groups achieve greater impacts. It is therefore recommended that duty bearers of Community-Based Financial Organisations (CBFO) programmes ensure adequate training in terms of quality and frequency for management of these groups. The VSLA methodology should be keenly followed with respect to management and group training to ensure that groups survive beyond three (3) years.

\section{References}

Bank, W. (2014). Global Financial Development Report.

Committee, R. (2008). Report of the committee on financial inclusion. India: Government of India Publication.

Deshingkar, P. (2008). Livestock and poverty reduction in India: Findings from the ODI livelihood options project. Retrieved from https://www.researchgate.net/publication

Fink, E. (2003). Population and sample. New Jersey: McGraw-Hill.

Ghana Stattical Service (2015). Ghana poverty mapping report. Retrieved from www2.statsghana.gov.gh/docfiles Miles, A. H. (1994). Qualitative data analysis: an expanded source book (2 $\left.2^{\text {nd }} \mathrm{ed}\right)$. CA:SAGE: Thousand Oaks.

Kothari, C. R. (2005). Research Methodology (Revised ed.).

Leeladhar, V. (2006). Indian banks and the global challenges. Mumbai.

Miller, C. (2005). Global perspective in rural finance and poverty alleviation. 4th AFRACA Microfinance Forum. 
Odell, K. (2010). Measuring the impact of microfinance: Taking another look. Grameen Foundation Publication Series.

Online, G. (2017, January 25). Graphic Online. Retrieved from http://www.graphic.com.gh/features/opinion

Oji, C. K. (2015, February). Promoting financial inclusion for inclusive growth in Africa. African Perspectives: Global Insights.

Ragin, C. (1994). Constructing social research. Thousand Oaks, CA: Pine Forge.

Rogers, E. (1996). Hypothesis testing objectives. London: Course Hero Inc.

Richter, P. (2011). Rural policy brief. International Labour Office Publication.

Thorat. (2006). Microfinance in India: Sectoral issues and challenges, in towards a sustainable microfinance outreach in India. New Delhi NABARD, 27-42.

Triki, T., \& Faye, I. (2013). Financial inclusion in Africa. Tunisia: African Development Bank.

Turner, A. G. (2003). Sampling frame and master samples. New Jersey: Prentice Hall. 